\title{
HUBUNGAN ANTARA KEPEMIMPINAN KEPALA PUSKESMAS DAN KARAKTERISTIK PETUGAS DENGAN KINERJA PETUGAS GIZI PUSKESMAS DI KABUPATEN KARAWANG TAHUN 2007
}

\author{
Endah Purwanti* dan Dian Ayubi**
}

\begin{abstract}
Number of malnutrion of children under five year increased in Karawang District during 2001-2006. This situation represents a low performance of nutrient staff. Performance of nutrition staff is related to puskesmas 's head leadership. This research aim is to assess relationship between performance of puskesmas's head leadership with nutrition staff in Karawang. The study design was a cross-sectional study. Total sample was 43 person nutrition staff in all puskesmas in Karawang. Data were analysed using multiple logistic regression. Result of this research found nutrition staff performance shows goodness $(55,8 \%)$ in general, but management of malnutrition chidren under five years is still unsatisfied. Puskesmas's head leadership has a largest association with nutrition staff performace compared to other variables.. Staff who perceived good on puskesmas head leadership will have 13 times greater to have good performencec than staff who perceived poor. Karawang Health District Office should conduct a leadership training for nutrition staff and also for the head of Puskesmas.
\end{abstract}

\section{Keyword: leadership, performance}

\section{Pendahuluan}

Upaya penanggulangan masalah gizi khususnya pada anak usia di bawah lima tahun (balita) masih sangat diperlukan (1). Perkembangan kasus balita gizi buruk Kabupaten Karawang, menurut hasil laporan dari Dinas Kesehatan Kabupaten Karawang dalam kurun waktu 5 tahun terakhir terjadi kenaikan persentase sekitar 0,59\% kasus, yaitu dari 1,17\% pada tahun 2002 dan 1,76\% pada akhir bulan Mei 2006. Tepatnya saat ini kasus gizi buruk berjumlah 2.058 balita dimana 11 menderita marasmus, 3 anak menderita marasmus-kwasiorkor dan 17 anak diantara mereka telah meninggal dunia. Sampai akhir Mei 2006 balita gizi buruk yang sudah dirawat sebanyak 16 anak dan yang masih dirawat di RSUD ada 3 orang (2)

Cakupan program gizi diantaranya penca-paian status gizi merupakan hasil kerja/kinerja program itu sendiri. Berhasil atau tidaknya pelak-sanaan pemantauan status gizi balita tidak terlepas dari peran kepemimpinan kepala Puskesmas dalam memberikan motivasi, arahan atau tuntunan kepada tenaga pelaksana gizi dalam melaksanakan tugasnya. Kepemimpinan adalah sebagai kemampuan untuk mempengaruhi suatu kelompok kearah tercapainya tujuan (3).

Menurut hasil penelitian Ayubi (2006) didapatkan bahwa kepemimpinan transformasional yang kuat mempengaruhi kinerja program imunisasi menjadi lebih baik, meskipun dalam keterbatasan biaya. Kepemimpinan transformasional mampu menumbuhkan semangat resourcefulness pengelola program imunisasi baik di tingkat Dinas Kesehatan Kabupaten/Kota maupun di tingkat puskesmas (4).

Penelitian ini bertujuan untuk mengetahui hubungan antara kepemimpinan kepala puskesmas dan karakteristik petugas dengan kinerja petugas gizi. Kinerja petugas gizi didasarkan pada pelaksanaan tugas sesuai tupoksi (tugas pokok dan fungsi) petugas gizi di Kabupaten Karawang. Penelitian ini mempunyai satu variabel terikat yaitu kinerja petugas gizi dalam melaksanakan kegiatan sesuai tupoksi, yang terdiri dari kegiatan rutin dan penatalaksanaan kasus balita gizi buruk. Variabel bebas

\footnotetext{
* Kepala Puskesmas Anggadita, Kabupaten Karawang, Jawa Barat

** Staf Pengajar Departemen Pendidikan Kesehatan dan Ilmu Perilaku Fakultas Kesehatan Masyarakat Universitas Indonesia
} 
yaitu kepemimpinan kepala puskesmas (variabel organisasi) dan karak-teristik individu petugas gizi yang mempengaruhi kinerja yang terdiri dari umur, jenis kelamin, lama kerja, pendidikan, pengetahuan (variabel individu) dan pelatihan, motivasi diri petugas gizi (variabel psikologis).

\section{Metodologi}

Jenis rancangan penelitian yang digunakan adalah desain potong lintang (cross-sectional). Penelitian dilakukan di 43 Puskesmas di Kabupaten Karawang, yang dilakukan pada bulan Februari 2007 sampai dengan Mei 2007.

Populasi yang diambil adalah seluruh petugas gizi Puskesmas. Pengambilan sampel untuk petugas gizi puskesmas dilakukan secara total sampling yang berjumlah 43 orang di Kabupaten Karawang. Data dikumpulkan dengan memberikan kuesioner kepada petugas gizi Puskesmas dimana pertanyaan pada setiap kuesioner dikelompokkan menjadi tiga yaitu data karakteristik individu petugas gizi puskesmas, persepsi petugas gizi tentang kepemimpinan kepala puskesmas dan kinerja petugas gizi berupa kegiatan petugas gizi sesuai tupoksi rutin dan penatalaksanaan kasus gizi buruk di wilayahnya masing-masing, serta bukti fisik arsip-arsip laporan bulanan selama kurun waktu 3 bulan terakhir yaitu bulan Januari 2007 sampai akhir Maret 2007.

Analisis multivariat yang digunakan adalah uji regresi logistik ganda, yang bertujuan untuk mengestimasi secara valid hubungan antara beberapa variabel utama/ independen dengan variabel dependen. Semua analisis dilakukan menggunakan program komputer.

\section{Hasil}

Dari Tabel 1 terlihat bahwa rerata skor tertinggi pada kegiatan rutin petugas gizi terletak pada kegiatan melaksanakan pencatatan dan pelaporan, hal ini didukung oleh bukti fisik yang ditemukan dengan nilai rerata total 0,88 (skala $0-1$ ).

Tabel 1

Deskripsi Rerata Skor Butir-butir Kinerja Petugas Gizi Puskesmas dan Dimensinya di 43 Puskesmas Kabupaten Karawang Tahun 2007

\begin{tabular}{lc}
\multicolumn{1}{c}{ Butir Kinerja Petugas Gizi } & Skor (1-4) \\
\hline \hline${ }^{*}$ Kegiatan rutin petugas gizi & 52,4 \\
Merencanakan kegiatan gizi & 3,05 \\
Melaksanakan kegiatan gizi & 3,00 \\
Melaksanakan koordinasi kegiatan gizi & 3,00 \\
Melaksanakan pemantauan dan penilaian & 3,09 \\
Melaksanakan pembinaan kegiatan perbaikan gizi & 3,17 \\
Melaksanakan pencatatan dan pelaporan & 3,33 \\
\hline * Kegiatan penatalaksanaan gizi buruk & 68,1 \\
Validasi dan hasil laporan & 2,55 \\
Melakukan rujukan & 2,40 \\
Pemberian PMT pemulihan & 3,57 \\
Penanggulangan kekurangan Zat gizi mikro & 2,05 \\
Evaluasi perkembangan berat badan balita gizi buruk & 2,20 \\
Persiapan tindak lanjut dirumah & 2,78 \\
Pengamatan terhadap balita gizi buruk & 2,10 \\
Pencatatan dan pelaporan & 2,68 \\
\hline Bukti fisik kinerja & Skor (0-1) \\
Laporan LB1 & 6,18 \\
Laporan F3 gizi & 0,93 \\
Laporan Distribusi Vitamin A & 0,95 \\
Laporan distribusi tablet Fe & 0,95 \\
Laporan sarana perbaikan gizi & 0,88 \\
Laporan daftar nama balita gizi buruk & 0,95 \\
\hline & 0,72 \\
\hline
\end{tabular}


Berdasarkan rerata lalu dilakukan kategorisasi kepemimpinan kepala puskesmas. Tabel 2 menun-jukkan bahwa bahwa 58,1\% Puskesmas mempunyai kepemimpinan kepala Puskesmasnya baik, dan faktor komunikasi mempunyai nilai tertinggi yaitu 55,8\%. Sedangkan nilai terendah terdapat pada faktor koordinasi yaitu $44,2 \%$.

Tabel 2

Distribusi Puskesmas Menurut Kepemimpinan Kepala Puskesmas dan Dimensinya di 43 Puskesmas Kabupaten Karawang Tahun 2007

\begin{tabular}{llll}
\hline \multicolumn{1}{c}{ Variabel } & \multicolumn{1}{c}{ Kategori } & N & Persentase \\
\hline \hline Kepemimpinan Kepala Puskesmas & Berata Skala 100) & & \\
& Kaik $(\geq 83,9)$ & 25 & 58,1 \\
- Koordinasi & Kurang $(<83,9)$ & 18 & 41,9 \\
& Baik $(\geq 85,9)$ & 19 & 44,2 \\
- Motivasi & Kurang $(<85,9)$ & 24 & 55,8 \\
& Baik $(\geq 80,8)$ & 23 & 53,5 \\
- Supervisi & Kurang $(<80,8)$ & 20 & 46,5 \\
& Baik $(\geq 76,2)$ & 21 & 48,8 \\
- Komunikasi & Kurang $(<76,2)$ & 22 & 51,2 \\
& Baik $(\geq 90,9)$ & 24 & 55,8 \\
- Pendelegasian wewenang & Kurang $(<90,9)$ & 19 & 44,2 \\
& Baik $(\geq 85,8)$ & 21 & 48,8 \\
\hline \hline
\end{tabular}

Tabel 3 memperlihatkan bahwa $62.8 \%$ petugas pernah mendapatkan pelatihan gizi dan $48.8 \%$ petugas berpengetahuan baik tentang tupoksi gizi dan penanganan balita gizi buruk.

Tabel 3

Distribusi Responden Menurut Karakteristik Individu di 43 Puskesmas di Kabupaten Karawang Tahun 2007

\begin{tabular}{lll}
\hline \multicolumn{1}{c}{ Karakteristik } & $\mathrm{n}$ & Persentase \\
\hline Jenis Kelamin & & \\
• Laki-laki & 13 & 30.2 \\
• Perempuan & 30 & 69.8 \\
Umur & & \\
- Muda & 19 & 44.2 \\
• Tua & 24 & 55.8 \\
Pendidikan terakhir & & \\
- SMU/sederajat & 17 & 39.5 \\
- Perguruan Tinggi & 26 & 60.5 \\
Lama kerja & & \\
- Baru & 22 & 51.2 \\
• Lama & 21 & 48.8 \\
Pelatihan Gizi & & \\
- Pernah & 27 & 62.8 \\
Pengetahuan & 16 & 37.2 \\
- Baik (> skor 64 skala 100) & & \\
- Kurang & 21 & 48.8 \\
Motivasi Diri & 22 & 51.2 \\
• Baik (> skor 87 skala 100) & & \\
- Kurang & & \\
\end{tabular}


Pemilihan model dilakukan dengan melakukan analisis hubungan antara kinerja dengan kepemimpinan dan semua faktor karakteristik individu, yaitu umur. jenis kelamin, pendidikan, pelatihan, lama kerja, pengetahuan dan motivasi diri. Bila hasil analisis mendapatkan nilai $\mathrm{p}<$ 0,25 maka variabel tersebut dapat dimasukan dalam analisis multivariat. Variabel tersebut adalah pendidikan terakhir, pelatihan, dan motivasi,
Tabel 4 menginformasikan bahwa variabel kepemimpinan kepala puskesmas mempunyai hubungan yang paling besar terhadap kinerja petugas gizi daripada variabel lainnya. Petugas gizi yang mempersepsikan kepemimpinan kepala puskesmasnya baik akan memberikan peluang sebesar 12.7 kali lebih besar untuk mempunyai kinerja yang baik daripada petugas gizi yang mempersepsikan buruk atas kepemimpinan kepala puskesmasnya.

Tabel 4

Regresi Logistik Ganda Antara Kepemimpinan Kepala Puskesmas dan Karakteritik Individu dengan Kinerja Petugas Gizi

\begin{tabular}{lccccc}
\hline \multicolumn{1}{c}{ Variabel } & B & SE & Wald & Sig & OR \\
\hline \hline Kepemimpinan kepala Puskesmas & 2,486 & 0,881 & 7,962 & 0,005 & 12,794 \\
Motivasi diri petugas gizi & 0,408 & 0,778 & 0,276 & 0,600 & 1,504 \\
Pendidikan terakhir petugas gizi & 0,833 & 0,804 & 1,075 & 0,300 & 2,300 \\
Pelatihan gizi yang diikuti & 1,891 & 0,944 & 4,009 & 0,045 & 6,625 \\
\hline \hline
\end{tabular}

\section{Pembahasan}

Apabila dilihat dari pelaksanaan kegiatannya (Tabel 1), menunjukan bahwa kinerja petugas gizi yang baik pada pelaksanaan kegiatan rutin sebesar 55,8\%, sedangkan pada kegiatan penatalaksanaan kasus gizi buruk hanya sebesar $46,5 \%$ puskesmas yang pelaksanaan kegiatannya sudah baik. Keadaan seperti ini dimungkinkan terjadi karena biasanya petugas gizi dalam melaksanakan tugasnya menganggap sebagai tugas rutin dan hanya menunggu intruksi dari kepala puskesmasnya ataupun Dinas Kesehatan Kabupaten. Ismitaty menemukan bahwa $59.7 \%$ petugas gizi memiliki kinerja baik di Propinsi Sumatera Selatan (5).

Kepemimpinan kepala puskesmas mem-punyai pengaruh paling besar terhadap kinerja petugas gizi Puskesmas dibandingkan variabel lainnya Hal ini sesuai dengan teori menurut kriteria Baldridge bahwa kesuksesan atau kegagalan suatu perusahaan tergantung kepada kualitas kepemimpinannya, dengan cara melakukan penilaian terhadap kemampuan pemimpin dan sistem kepemimpinannya serta mengaitkannya dengan hasil-hasil yang dicapai (6). Penelitian yang dilakukan oleh Karolin (2000) dimana faktor kepemimpinan kepala Puskesmas sangat berperan dalam pelaksanaan program gizi di Puskesmas di Kota Bogor (7).

Penelitian Scarborough menemukan bahwa para pemimpin memainkan peran penting dalam keberhasilan melakukan perubahan budaya (8). Penelitian Adiono menemukan bahwa perawat yang mempersepsikan kepemimpinan atasannya baik memiliki peluang untuk mempunyai kinerja baik sebesar 4.3 kali dibandingkan dengan perawat yang mempersepsikan kepemimpinan atasannya kurang baik. Kinerja perawat dinilai berdasarkan kesesuaian tindakan keperawatannya terhadap standard operating procedure (SOP) (9)

Penelitian ini menemukan bahwa untuk mencapai kinerja petugas gizi yang baik diperlukan tidak hanya kepemimpinan yang baik atas kepala puskesmas juga ditentukan oleh motivasi petugas itu sendiri, pendidikan yang memadai dan pelatihan gizi.

\section{Simpulan}

Dari hasil analisa dan pembahasan variabelvariabel yang diteliti dapat diambil kesimpulan sebagai berikut :

a. Kepemimpinan kepala Puskesmas di Kabupaten Karawang pada umumnya baik $(58,1 \%)$, namun dalam pelaksanaan fungsi koordinasi, supervisi dan pendelegasian wewenang masih kurang baik berkisar antara $44,2 \%-48,8 \%$.

b. Kinerja petugas gizi Puskesmas di Kabupaten Karawang secara umum juga sudah baik (55,8\%), didukung dengan bukti fisik berupa arsip pelaporan sebagian besar (86\%) sudah baik. Namun pada item penatalaksanaan kasus balita gizi buruk memperlihatkan kurang baik dengan nilai $46,5 \%$.

c. Kepemimpinan kepala puskesmas, pendidikan terakhir, pelatihan dan motivasi petugas merupakan variable yang berhubungan secara statistic dengan kinerja petugas gizi puskesmas. Variabel kepe-mimpinan memiliki hubungan yang paling besar dibandingkan dengan variabel lainnya.

\section{Saran}

Bagi Dinas Kesehatan di Kabupaten Kara-wang diharapkan untuk lebih memperhatikan masalah pelatihan yang mendukung kinerja petugas gizi Puskesmas. Pelatihan yang diharapkan adalah pelatihan dengan metode baru yang memungkinkan petugas gizi untuk berkreativitas secara positif dan mampu mengaplikasikan hasil pelatihan dalam pelaksanaan tugas sehari-hari di Puskesmas. Guna meningkatkan pelaksanaan kepemimpinan kepala Puskesmas diusulkan ke Dinas Kesehatan Kabupaten untuk melanjutkan program pelatihan khusus dalam hal kepemimpinan misalnya LMCB. 


\section{DAFTAR PUSTAKA}

1. Permaesih, dkk, 2000, Prevalensi Anak Balita di Wilayah Indonesia Bagian Timur dalam Penelitian Gizi dan Makanan, Puslitbang Gizi, Bogor, 2000

2. Dinas Kesehatan Kabupaten Karawang, Laporan Tahunan Program Gizi, Dari Tahun 2002 Sampai dengan Tahun 2006, Karawang, 2002-2006.

3. Robbins, S.P. 2006. Perilaku Organisasi, Edisi Kesepuluh/ Edisi Lengkap, PT. Index Kelompok Gramedia, Jakarta.

4. Ayubi, D. 2006. Peran Kepemimpinan Transformasional Pengelola Program Imunisasi Dinas Kesehatan Kabupaten/Kota Terhadap Status Imunisasi Anak di Tujuh Propinsi Di Indonesia Tahun 2004, Disertasi Program Studi Ilmu Kesehatan Masyarakat Universitas Indonesia, Jakarta.

5. Ismitaty, A. 2004, Faktor-faktor yang Berhubungan Dengan Kinerja Petugas Gizi Puskesmas di Propinsi
Sumatra Selatan, Thesis Program Pasca Sarjan IKMUI, Depok

6. Haris, A. 2005. 7 Pilar Perusahaan Unggul, Implementasi Kriteria Baldrige Untuk Meningkatkan Kinerja Perusahaan, PT. Gramedia Pustaka Utam,Jakarta.

7. Karolin, C. 2000, Evaluasi Manajemen Pelaksanaan Program Gizi Puskesmas Kota Bogor Tahun 1999, Thesis Program Pasca Sarjan IKM- UI, Depok.

8. Scarborough, J.D. 200, Transforming leadership in the manufacturing industry. Journal of Industrial Technology; February - April 2001; Vol. 17; No. 2; pg. 2 $-13$

9. Adiono, S. 2002, Analisis kepemimpinan yang mendorong iklim kerja dan motivasi kerja serta dampaknya terhadap kinerja perawat di rumah sakit se-Kota Palu. Tesis. Program Studi Magister Kesehatan Masyarakat. Fakultas Kesehatan Masyarakat Universitas Indonesia. 